\title{
REPRESENTATION OF MUTUAL TERMS AND RESEARCH SKILLS TOWARDS GRADE POINT AVERAGE: EXPLORATION STUDY
}

\author{
Hasan Subekti ${ }^{1),}$ Wachidatul Linda Yuhanna ${ }^{2),}$ Herawati Susilo ${ }^{3),}$ \\ Ibrohim 4), dan Hadi Suwono ${ }^{5)}$ \\ 1) Pascasarjana Universitas Negeri Malang dan Pendidikan Sains Universitas Negeri Surabaya \\ 2) Pascasarjana Universitas Negeri Malang dan Pendidikan Biologi Universitas PGRI Madiun \\ ${ }^{3,4,5)}$ Pendidikan Biologi Universitas Negeri Malang \\ ${ }^{3)}$ email: herawati.susilo.fmipa@um.ac.id
}

Diterima 12 Maret 2018 disetujui 14 April 2018

\begin{abstract}
Research activities have been studied extensively to improve the quality of learning, especially in higher education. This research aims to explore the mastery of the term of research (TR or IR) and research skills (RS or KR) of toward of grade point average (GPA or IPK). This research uses a quantitative approach to the object of students in natural science education program a number of 67 people who follow biotechnology courses academic year 2017/2018. Data collection with tests and aggregation of documentation. Data analysis technique is done by quantitative descriptive analysis. The decision indicates that the exact number of IR is 66.0 (easy category) and $K S$ is 65.8 (short category). The result of correlation analysis shows $F_{\text {count }}=$ $6,147>3,140=F_{\text {table }}=(0,05 ; 2 ; 64)$ or in other words there a relationship of IR and KR collectively to GPA. This study concludes that there is a significant correlation between IR and $K R$ guards in the same period as the GPA. Based on the investigation, it is expected to provide benefits as one of the considerations for the selection and determination of learning mods related to learning. It is expected to be useful as a consideration for the selection and determination of study-related modes for improvement.
\end{abstract}

Keywords: Research term, research placement, exploration

\section{PENDAHULUAN}

Riset, teknologi dan pendidikan tinggi merupakan komponen yang semakin urgen guna membangun daya saing bangsa, dan peningkatan kesejahteraan serta keadilan (Kemenristekdikti, 2018c). Dalam menghadapi era globalisasi, banyak kehidupan masyarakat dipengaruhi oleh perkembangan ilmu pengetahuan dan teknologi (Putra et al., 2016). Memandang fenomena era revolusi industri 4.0 ini, diprediksi era ini akan mendisrupsi (menghilangkan) ragam aktivitas manusia, termasuk di dalamnya bidang ilmu pengetahuan dan teknologi (iptek) (Kemristekdikti, 2018a) serta luaran pendidikan tinggi. $\mathrm{Ke}$ depan, Perguruan Tinggi perlu untuk difasilitasi dan didorong guna lebih banyak menghasilkan inovasi dan invensi yang bermanfaat secara langsung kepada masyarakat (DRPM, 2018). Namun, perlu diingat bahwa, perubahan merupakan sesuatu yang tidak bisa harus dihadapi dan menjadi kata kunci dalam perkembangan global, dunia kerja, dan kehidupan. Bertolak dari paparan tersebut, menyiapkan mahasiswa, baik sebagai pribadi maupun sebagai bagian dari masyarakat, secara efektif mendapatkan manfaat dari perubahan tersebut, dipadang urgen bagi mahasiswa, khususnya pada mahasiswa calon guru IPA (Sains).

Mengembangkan KR merupakan salah satu tujuan utama dalam dunia pendidikan (Anggraeni, Adisendjaja, \& Amprasto, 2017). Riset, teknologi dan pendidikan tinggi merupakan faktor yang semakin penting dalam membangun daya saing bangsa, meningkatkan 
kesejahteraan dan keadilan (Kemenristekdikti, 2018c). KR adalah tujuan utama pendidikan (Anggraeni et al., 2017), di mana sebagian besar dipelajari dan diterapkan dengan mengintegrasikan keterampilan dan kemampuan kognitif untuk mengembangkan pengetahuan sains (Kuo, Wu, Jen, \& Hsu, 2015). Tampaknya, KR semakin dianggap sebagai komponen penting pendidikan sains di tingkat sekolah (Kapon, 2016) dan pendidikan tinggi. Sejalan dengan gagasan ungkapan tersebut, riset merupakan sarana penting untuk meningkatkan mutu pembelajaran (Widodo, 2016; Subekti \& Martini., 2016; Masfingatin et al., 2017). KR mencoba untuk mengungkap dan menjawab ragam pertanyaan dan menyelesaikan masalah secara ilmiah logis.

Salah satu langkah untuk mengembangkan KR meliputi metodologi pengetahuan dan berintegrasi dengan pengetahuan ilmiah, penalaran ilmiah dan pemikiran kritis (Adisendjaja et al., 2017). Konsep seperti keterampilan riset tidak muncul dari ketiadaan, namun secara historis terkait dengan pengembangan sains dan jenis penyelidikan terkait lainnya, misalnua penyelidikan filosofis, penyelidikan teologis dan lain-lain (Bang, 2018). Proses mengembangkan KR dapat digambarkan sebagai ragam kegiatan dalam bentuk pemecahan masalah (Nowak, et al., 2013). Sejalan dengan ungkapan tersebut, Adisendjaja et al., (2017) menyatakan bahwa keterampilan riset atau penyelidikan ilmiah dapat digambarkan sebagai sebuah proses untuk melakukan pekerjaan dan menghasilkan pengetahuan dari ilmuwan. Senada dengan hal tersebut, Hanauer, et al., (2009) mengidentifikasi enam pendekatan dalam penilaian keterampilan riset, yaitu: (a) kemampuan inti dari penyelidikan ilmiah; (b) tahapan penyelidikan ilmiah; (c) kemampuan praktis; (d) kemampuan praktis dan konsep bukti; (e) penilaian kinerja sains; dan (f) sains sebagai literasi tindakan.

Mengajarkan KR pada kelas yang interdisipliner merupakan sebuah tantangan dalam mengelola proses pembelajaran (Berry, 2017). Namun demikian, fakta menunjukkan di sekolah menengah dan perguruan Tinggi yang telah dikemukakan itu kita akan dengan mudah menyimpulkan bahwa pembelajaran di sekolah menengah dan perguruan tinggi di Indonesia tidak berkepentingan mempersiapkan manusia Indonesia untuk hidup di abad sekarang yaitu abad 21 (Corebima, 2016) atau saat ini lebih popular dengan sebutan era revolusi industri 4.0. Dengan demikian, dalam mengembangkan Keterampilan riset berpotensi melibatkan berbagai kemampuan yang ilmuwan gunakan untuk menyelidiki dunia alami (Yeh et al., 2012). Sejalan ungkap tersebut, (Sudira, 2015) mengatakan bahwa bagi masyarakat Indonesia belajar untuk bekerja merupakan sebagian saja dari kebutuhan hidup. Karena itu, (Adisendjaja et al., 2017) menegaskan bahwa Penyelidikan merupakan tujuan utama reformasi pendidikan sains di seluruh dunia. Keterampilan riset digunakan ilmuwan dan mencerminkan bagaimana proses sains (Yang \& Liu, 2016) dan sikap tersebut berjalan dengan baik.

Berkaitan dengan pengembangan keterampilan riset tidak hanya mengacu pada kemampuan berpikir fundamental yang dimiliki ilmuwan dan siswa didorong untuk berkembang saat mereka belajar tentang alam, namun juga beragam kegiatan yang dapat digunakan untuk meningkatkan kemampuan berpikir ilmiah siswa (Yeh et al., 2012). Studi ini meneliti pemahaman guru sains tentang $\mathrm{KR}$ dalam program 
pengembangan profesional guru. Sejalan dengan uraian tersebut, (Akpan, 2017) himbauan mengenai pentingnya penelitian pendidikan sains masa depan, bagaimana kita melibatkan peserta didik dengan sains, ilmuwan, dan masyarakat dengan cara mengembangkan keingintahuan dan ketertarikan dengan dunia dan melihat sains sebagai cara untuk menghasilkan ide baru dan pengetahuan yang bisa berkontribusi terhadap peningkatan kualitas hidup manusia, dimana salah satunya melalui perkuliahan Bioteknologi

Penguasaan inteligen (intelligence) dan bioteknologi merupakan salah satu tantangan dalam menghadapi era baru yang dinamakan revolusi industri 4.0 atau revolusi industri dunia keempat (Kemristekti, 2018b). Deskripsi capaian pembelajaran pada mata kuliah Bioteknologi adalah membahas tentang kajian dan pengembangan nalar tentang prinsip-prinsip bioteknologi (makanan) yang meliputi bioteknologi fermentasi, bioteknologi pertanian, bioteknologi peternakan, dan bioetik, dengan mengintegrasikan perspektif kewirausahaan dan lingkungan. Perkuliahan dilaksanakan dengan ekplorasi, penugasan, presentasi, dan diskusi (Jatmiko et al., 2014). Salah satu cara untuk mengembangkan keterampilan riset melalui tiga jenis kegiatan, yaitu: (1) penyelidikan, (2) mengembangkan argumentasi atau penjelasan dari solusi, dan (3) mengevaluasi data sebagai bukti teori dan model yang diajukan (Kruit, et al., 2018). Berkaitan dengan urgensi proses pembelajaran berbasis penyelidikan memungkinkan siswa mengembangkan kemampuan dasar dan membangun pemahaman konseptual tentang Keterampilan riset (Yang \& Liu, 2016). Dengan demikian, dalam mengembangkan Keterampilan riset berpotensi melibatkan berbagai kemampuan yang ilmuwan gunakan untuk menyelidiki dunia alami. (Yeh et al., 2012). Merujuk pada pandangan Lederman et al., (2014) tentang pentingnya aspek-aspek yang sifat pengetahuan ilmiah tidak dianggap sebagai daftar yang komprehensif, melainkan seperangkat gagasan yang penting bagi mahasiswa untuk belajar tentang pengetahuan ilmiah.

Bertolak dari paparan tersebut, tujuan penelitian ini mengekplorasi penguasaan istilah riset dan keterampilan riset mahasiswa calon guru IPA ditinjau dari indeks prestasi kumulatif. Penelitian ini diharapkan menjadi bahan rujukan dan pertimbangan dan terobosan baru dalam memilih strategi, model, cara, pembelajaran yang tepat untuk mengembangkan kompetensi mahasiswa calon guru sains tersebut.

\section{METODE}

Penelitian ini menggunakan pendekatan kuantitatif. Objek adalah mahasiswa calon guru IPA pada semester 3 pada tahun akademik 2017/2018 sebanyak 67 mahasiswa yang memprogram mata kuliah Bioteknologi. Metode yang pilih dalam penelitian ini ialah metode deskriptif dengan pendekatan kuantitatif. Proses pengumpulan data yang digunakan ialah tes tulis dan dokumen berupa IPK.

Instrumen penelitian yang dikembangkan terdiri dari dua jenis Instrumen, yaitu instrumen penguasaan IR dan instrumen KR. Instrumen IR dikembangkan dengan memodifikasi Instrumen (Schaub et al., 2016), dengan bentuk soat tulis tipe menjodohkan sebanyak 14 istilah riset yang terkait penulisan artikel, yaitu abstract; articles; citation; DOI; falsification; full text; keyword; literature review; open access; parafrase; plagiarisme; reference; review; dan summarizing. Adapun 
instrumen KR, dikembangkan mengacu pada 6 tahapan penyelidikan ilmiah (Hanauer et al., 2009), yang terdiri dari 27 pertanyaan dengan rincian (1) mengidentifikasi masalah atau rumusan masalah (3 pertanyaan); (2) mengidentifikasi desain dari suatu eksperimen (6 pertayaan); 3) mengidentifikasi hipotesis (3 pertanyaan); (4) menganalisis prediksi (3 pertanyaan); (5) menganalisis penerapan metode statistik (9 Pertanyaan); dan (6) manganalisis penarikan kesimpulan (3 pertanyaan). Semua soal yang pertanyaan tersebut berupa soal pilihan ganda.

Data yang dikumpulkan dari penyebaran tes IR dan tes KR dianalisis kemudian dihitung persentasenya. Kategorisasi pencapaian tes penguasaan IR, KR, dan IPK dibagi menjadi 5, yaitu: sangat tinggi $(\bar{X}+1.5 S D<X)$; tinggi $(\bar{X}+0.5 S D<X \leq \bar{X}+1.5 S D \bar{X})$;

cukup $\quad(\bar{X}-0.5 S D<X \leq \bar{X}+$ $1.5 S D \bar{X})$; rendah $(\bar{X}-0.5 S D<X \leq$ $\bar{X}-1.5 S D \bar{X})$, dan sangat rendah $(X \leq$ $\bar{X}-01.5 S D$ ) (Sugiono, 2013). Adapun kategorisasi koefisien korelasi, ialah: tidak ada hubungan (0.00-0.30); hubungan lemah $(0.30-0.49)$; hubungan moderat (0.50-0.69); hubungan kuat (0.70-089); hubungan sangat kuat (0.90-1.00); (Mukaka, 2012). Teknik analisis data dilakukan dengan analisis deskriptif kuantitatif

\section{HASIL DAN PEMBAHASAN}

Data yang diperoleh melalui kegiatan ini meliputi data penguasaan IR dan data kemampuan KR mahasiswa serta IPK Paparan secara lebih rinci tentang (1) informasi demografi partisipan; (2) analisis penguasaan IR; (2) analisis KR (3) hubungan antara penguasaan IR dan KR ditinjau dari IPK, disajikan sebagai berikut.

\section{Informasi Demografi Partisipan}

Penelitian eksploratif tentang penguasaan IR dan KR ini dilakukan pada mahasiswa calon guru IPA yang memprogram mata kuliah Bioteknologi pada tahun akademik 2017/2019 sejumlah 67 Mahasiswa. Dari segi gender, riset ini didominasi oleh mahasiswa mahasiswa putri sejumlah 60 $(89,4 \%)$ mahasiswa dan 7 (10,4\%) mahasiswa putra. Rentang IPK 2.65 (terendah)-3.89 (tertinggi), dengan rerata IPK sebesar 3.44.

\section{Analisis Penguasaan Istilah Riset}

Penguasaan terkait istilah riset (IR) akan memegang peranan penting dalam suatu penelitian, terkait bagaimana informasi dibuat, disebarluaskan, dan digunakan dalam penelitian, sehingga mahasiswa menjadi melek (literet) informasi. Para peneliti menguji empat belas istilah melek informasi (Schaub et al., 2016) atau disebut penguasaan istilah riset . Hasil analisis data menunjukkan rata-rata skor KR adalah 65.8 (berkategori sedang) dari 100 poin.

Persentase kemampuan rerata-rata skor IR sebesar 66.0 (berkategori sedang) dari 100 poin. Mengacu pada Gambar 1 di atas, tampak bahwa pengusaan IR yang skor rendah ialah parafrase $(31,3)$ dan open access $(47,8)$. Sedangkan pengusaan IR yang menunjukkan skor tinggi ialah reference (79.1); keyword (80.6); plagiarisme (94.0); dan abstract (95.5). Keterampilan riset tidak hanya mengacu pada kemampuan berpikir fundamental yang dimiliki ilmuwan dan siswa didorong untuk berkembang saat mereka belajar tentang alam, namun juga beragam kegiatan yang dapat digunakan untuk meningkatkan kemampuan berpikir ilmiah siswa (Yeh et al., 2012). Merujuk pendapat (Schaub et al., 2016), empat belas istilah tersebut adalah istilah yang digunakan para peneliti atau penulis di lapangan, sehingga supaya lebih efektif 
tidak hanya sekedar mendefinisikan saja, namun lebih ditekankan pada konsep

pencapaian indikator jawaban benar IR disajikan pada Gambar 1. yang mendasari dan gambaran ide-ide konkretnya. Visualisasi persentase

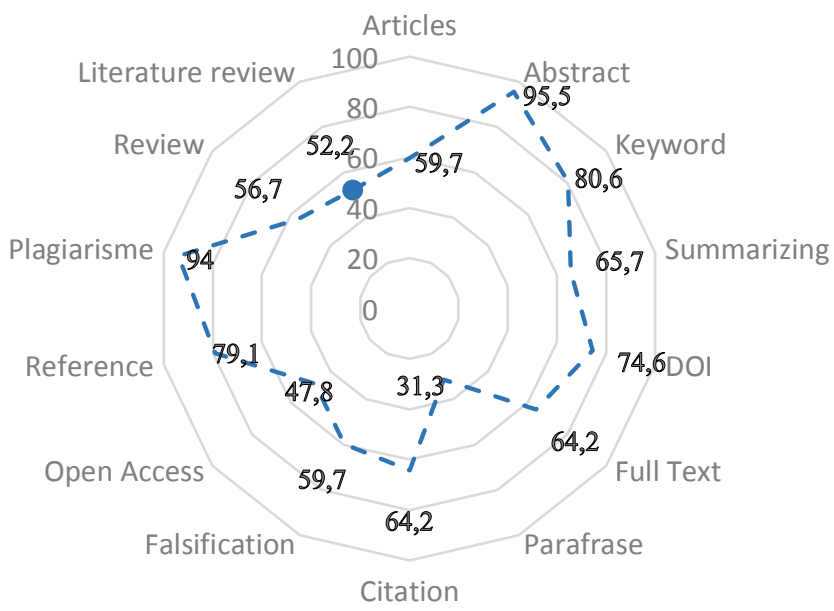

Gambar 1. Persentase Jawaban Benar IR

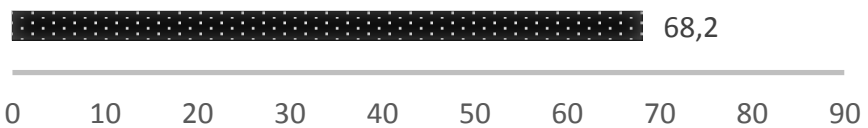

Gambar 2. Persentase Jawaban Benar KR

\section{Analisis Keterampilan Riset}

Penguasaan keterampilan riset (KR) menyediakan sarana yang baik untuk membantu pembiasaan berpikir pada mahasiswa. Komponen riset terdiri dari: latar belakang, prosedur, pelaksanaan, hasil riset dan pembahasan serta publikasi hasil riset (Masfingatin et al., 2017). Seluruh komponen tersebut memberikan makna penting yang dapat dilihat cara memformulasi dan menyelesaikan permasalahan serta kemampuan dalam mengkomunikasikan manfaat hasil penelitian (Widodo, 2016). Hasil analisis data menunjukkan rata-rata skor KR adalah 65.8 (berkategori sedang) dari 100 poin. Visualisasi persentase pencapaian indikator jawaban benar KR disajikan grafik pada Gambar 2. 
Visualisasi Gambar 2 menunjukkan bahwa kemampuan Keterampilan riset mahasiswa yang bersifat fluktuasi. Data pada indikator (1) mengidentifikasi rumusan masalah 68,2 (berkategori sedang); (2) mengidentifikasi desain eksperimen 83,6 (berkategori sedang); mengidentifikasi hipotesis 87,3 (berkategori tinggi); menganalisis prediksi 55,8 (berkategori sedang); menganalisis penerapan metode statistik 52,4 (berkategori sedang); menganalisis penarikan kesimpulan 80,6 (berkategori tinggi). Persentase yang menunjukkan skor rendah adalah menganalisis prediksi $(51,7)$ dan menganalisis penerapan metode statistik (50.6). Hasil penelitian ini mendukung penelitian (Lederman et al., 2017) menyatakan sumber kebingungan terkait keterampilan riset antara lainnya adalah penggunaan kata prediksi. Prediksi tidak menebak hipotesis mana yang paling mungkin, dan mereka juga tidak menebak hasil eksperimen.

Tabel 1. Hasil Analisis Interval dan Persentase Penguasaan IR, RS, dan IPK

\begin{tabular}{|c|c|c|c|c|c|c|c|}
\hline \multirow{3}{*}{ No } & \multirow{3}{*}{ Kategori } & \multicolumn{6}{|c|}{ Jumlah } \\
\hline & & \multicolumn{2}{|l|}{ IR } & \multicolumn{2}{|l|}{$\mathbf{R S}$} & \multicolumn{2}{|l|}{ IPK } \\
\hline & & Interval & $\%$ & Interval & $\%$ & Interval & $\%$ \\
\hline 1 & Sangat Tinggi & $>99.9$ & 7.5 & $>82,7$ & 1.5 & $>3,7$ & 7.5 \\
\hline 2 & Tinggi & $77,2-\leq 99.8$ & 29.9 & $71,5-\leq 82,7$ & 31.3 & $3,5-\leq 3,7$ & 37.2 \\
\hline 3 & Sedang & $54,7-\leq 77,2$ & 28.4 & $60,2-\leq 71,5$ & 43.3 & $3,4-\leq 3,5$ & 17.5 \\
\hline 4 & Rendah & $32,2-\leq 54,7$ & 28.4 & $49,0-\leq 60, .2$ & 13.4 & $3,2-\leq 3.4$ & 26.5 \\
\hline Rerata $(\mathrm{X})$ & $\begin{array}{l}\text { Sangat Rendah } \\
\text { ta }(\mathrm{X})\end{array}$ & $\begin{array}{r}\leq 32,3 \\
66.0\end{array}$ & 6.0 & $\begin{array}{c}\leq 49,0 \\
65,8\end{array}$ & 10.4 & $\begin{array}{c}\leq 3,2 \\
3.4\end{array}$ & 10.4 \\
\hline \multicolumn{2}{|c|}{ Standar Deviasi (SD) } & 22,545 & & 11.246 & & 0,163 & \\
\hline
\end{tabular}

\section{Analisis Korelasi IR dan KR terhadap IPK}

Akses informasi yang semakin cepat, akurat, dan mudah merupakan kebutuhan dan mahasiswa, pendidik dan hampir pada kehidupan masyarakat modern. Berkaitan dengan hal ini, keterampilan literasi informasi sangat dibutuhkan dalam era informasi saat ini. Dengan demikian pengetahuannya dan penguasaan tentang teknologi urgen untuk dikembangkan dalam pembelajaran suapa senantiasa dapat bertahan hidup bahkan unggul dalam persaingan global. Di era globalisasi, banyak kehidupan masyarakat dipengaruhi oleh perkembangan ilmu pengetahuan dan teknologi (Putra et al.,
2016). Bagian ini dibahas Analisis Hubungan LI dan KPS terhadap IPK.

Mengacu Tabel 1, Penguasaan IR sebanyak $28.5 \%$ (berkategori rendah) dan $6.0 \%$ (berkategori sangat rendah). Hal mengindikasikan penguasaan IR perlu ditinggkatkan. Namun sebaliknya, penguasaan RS sebanyak $43.3 \%$ (berkategori sedang) dan $31.3 \%$ (berkategori tinggi). Ditinjau dari IPK, tampak nilai IPK berkategori tinggi (37.3\%) dan sangat tinggi (7.5\%).

Isu mendasarnya adalah berkembangnya penggunaan informasi ilmiah yang dimiliki oleh siswa untuk memecahkan masalah dalam kehidupan sehari-hari dan menghasilkan sumber ilmiah yang bermanfaat (Fakhriyah, Masfuah, Roysa, Rusilowati, \& Rahayu, 2017). Karena itu, (Adisendjaja et al., 2017) menegaskan 
bahwa penyelidikan merupakan tujuan utama reformasi pendidikan sains di seluruh dunia. Merujuk pada pendapat, (Suwono et al, 2017) yang menegaskan terkait peran lembaga pendidikan tinggi, seharusnya membantu para mahasiswa untuk memiliki pengetahuan yang memadai sehingga mereka dapat membuat pilihan berdasarkan informasi, terlibat dalam pengembangan sains, membuat keputusan mengenai masalah sains dan dampaknya terhadap teknologi dan masyarakat.

Tabel 2. Analisis Korelasi IR dan KR terhadap IPK

\begin{tabular}{|c|c|c|c|}
\hline Variabe & & IR & KR \\
\hline \multirow[t]{2}{*}{ KR } & $\begin{array}{l}\text { Pearson } \\
\text { correlation }\end{array}$ & 0,539 & \\
\hline & P-Value & 0,000 & \\
\hline \multirow[t]{2}{*}{ IPK } & $\begin{array}{l}\text { Pearson } \\
\text { correlation }\end{array}$ & 0,401 & 0,228 \\
\hline & $P$-Value & 0,000 & 0,063 \\
\hline
\end{tabular}

Merujuk Tabel 2, menunjukkan adanya hubungan antara IR dan KR berkategori moderat (0.539). Adapun hubungan antara IR dengan IPK berkategori moderat (0.401), serta adanya tidak hubungan (0.228) antara KR dengan IPK. Namun demikian, ditinjau dari hasil analisis korelasi berganda menunjukkan bahwa ada hubungan yang signifikan antara variabel IR dan KR secara bersama-sama terhadap IPK. Hal ini didasarkan pada hasil analisis data yang menunjukan, $F_{\text {hitung }}=6,147>3,140=$ $F_{\text {tabel }}=(0,05 ; 2 ; 64)$ atau dengan kata lain data mendukung untuk menolak $H_{0}$, dengan tingkat kepercayaan $95 \%$.

Studi ini meneliti tentang pemahaman guru sains mengenai keterampilan riset untuk mengembangan profesionalitas mereka. Namun demikian, penting untuk diingat bahwa aspek-aspek sifat pengetahuan ilmiah tidak dianggap sebagai daftar yang komprehensif, melainkan seperangkat gagasan penting bagi mahasiswa untuk belajar tentang pengetahuan ilmiah (N. G. Lederman et al., 2014). Sejalan dengan uraian tersebut, (Akpan, 2017) urgensi penelitian dalam pendidikan sains masa depan, bagaimana melibatkan peserta didik (mahasiswa) dengan sains, ilmuwan, dan masyarakat guna mengembangkan rasa ketertarikan dan keingintahuan dengan dunia sains agar dapat berkontribusi dalam meningkatkan kualitas hidup manusia.

\section{SIMPULAN}

Simpulan penelitian ini adalah Penelitian ini menyimpulkan ada hubungan yang signifikan antara variabel IR (LI) dan keterampilan riset secara bersama-sama terhadap indeks prestasi kumulatif (IPK). Hal ini didasarkan pada hasil analisis data yang menunjukan, $F_{\text {hitung }}=6,147>3,140=F_{\text {tabel }}=$ $(0,05 ; 2 ; 64)$ atau dengan kata lain data mendukung untuk menolak $H_{0}$, dengan tingkat kepercayaan 95\%. Disamping itu, hasil analisis data menunjukkan adanya hubungan antara IR dan KR berkategori moderat (0.539). Adapun hubungan antara IR dengan IPK berkategori moderat (0.401), serta adanya tidak hubungan (0.228) antara KR dengan IPK. Bertolak dari paparan kesimpulan tersebut, perlunya adanya penelitian lebih lanjut terkait cara maupun strategi untuk meningkatkan kemampuan riset sehingga berdampak baik terhadap kemampuan mahasiswa dan cerminan pembelajaran yang dilaksanakan.

\section{DAFTAR PUSTAKA}

Adisendjaja, Y. H., Rustaman, N. Y., Redjeki, S., \& Satori, D. (2017). Science teachers' understanding of scientific inquiry in teacher professional development. Journal of Physics: Conference Series, $\quad 812, \quad 1-8$. doi:10.1088/17426596/812/1/012054. 
Akpan, B. (2017). Science Education: A Global Perspective. Switzerland: Springer.

Anggraeni, N., Adisendjaja, Y. H., \& Amprasto, A. (2017). Profile of high school students' understanding of scientific inquiry. Journal of Physics: Conference Series, 895, 1-5. doi:10.1088/17426596/895/1/012138.

Bang, L. (2018). The inquiry of the cyclops: dewey's scientific inquiry Revisited. In K. OtrelCass (Ed.), Cultural, Social, and Political Perspectives in Science Education (Vol. 15, pp. 49-67). London: Springer International Publishing.

Berry, C. M. (2017). A technique for inspiring scientific inquiry using a creative scenario. The American Biology Teacher, 79(8), 671-677. doi:10.1525/ abt.2017.79.8.671.

Corebima, A. D. (2016). Pembelajaran Biologi di Indonesia Bukan untuk Hidup. Paper presented at the Biology Education Conference, Universitas Sebelas Maret (UNS), Surakarta. https://jurnal.uns. ac.id/prosbi/article/viewFile/564/ 5008.

Direktorat Riset dan Pengabdian Masyarakat (DRPM). (2018). Panduan Penelitian dan Pengabdian Kepada Masyarakat Edisi XII. Jakarta: Direktorat Jenderal Penguatan Riset dan Pengembangan, Kemristekdikti.

Fakhriyah, F., Masfuah, S., Roysa, M., Rusilowati, A., \& Rahayu, E. S. (2017). Student's science literacy in the aspect of content science? Jurnal Pendidikan IPA Indonesia, 6(1). doi:10.15294/ jpii.v6i1.7245.

Hanauer, D. I., Hatfull, G. F., \& JacobsSera, D. (2009). Active
Assessment: Assessing Scientific Inquiry (Vol. 2). New York: Springer Science.

Jatmiko, B., Widodo, W., Martini, \& Budiyanto, M. (2014). Buku Prototipe Kurikulum Pendidikan Sains Berorientasi KKNI. Surabaya: UNESA Press.

Kapon, S. (2016). Doing research in school: Physics inquiry in the zone of proximal development. Journal of Research in Science Teaching, 53(8), 1172-1197. doi:10.1002/tea.21325.

Kemristekdikti. (2018a). Pengembangan Iptek dan Pendidikan Tinggi di Era Revolusi Industri 4.0. Retrieved from https://www.ristekdikti.go.id/pen gembangan-iptek-danpendidikan-tinggi-di-erarevolusi-industri-4-0/.

Kemristekti. (2018b). Presiden Jokowi: Tantangan Kita ke Depan, Revolusi Industri 4.0.

Kemenristekdikti. (2018c). Kebijakan Kemenristekdikti Menghadapi Globalisasi Pendidikan \& Revolusi Industri 4.0 [Press release].

Kruit, P. M., Oostdam, R. J., Berg, E., \& Schuitema, J. A. (2018). Assessing students' ability in performing scientific inquiry: Instruments for measuring science skills in primary education. Research in Science \& Technological Education, 1-27. doi:10.1080/ 02635143.2017 .1421530 .

Kuo, C.-Y., Wu, H.-K., Jen, T.-H., \& Hsu, Y.-S. (2015). Development and validation of a multimediabased assessment of scientific inquiry abilities. International Journal of Science Education, 37(14), 23262357.doi:10.1080/09500693.201 5.078521 . 
Lederman, J., Lederman, N., Bartels, S., Jimenez Pavez, J., Lavonen, J., Blanquet, E., Yalaki, Y. (2017). Understandings of scientific inquiry: $\quad A n$ international collaborative investi-gation of seventh grade student. Paper presented at the ESERA 2017 Conference, Dubin City University, Irelend. https://www.researchgate.net/ publication/322603295.

Lederman, N.G., Antink, A., \& Bartos, S. (2014). Nature of science, scientific inquiry, and socioscientific issues arising from genetics: A pathway to developing a scientifically literate citizenry. Science and Education, 23(2), 285-302. doi:10.1007/s11191-012-9503 -3.

Masfingatin, T., Murtafi'ah, W., \& Krisdiana, I. (2017). Pembelajaran Berbasis Riset untuk Mengembangkan Kompetensi Profesional dan Melatihkan Self Regulated Learning pada Mata Kuliah Geometri (pp. 1-50). Universitas PGRI Madiun: Direktorat Riset dan Pengabdian Masyarakat (DRPM).

Mukaka, M. M. (2012). Statistics corner: A guide to appropriate use of correlation coefficient in medical research. Malawi Medical Journal; 24(3): September, 24(3), 69-71 Retrieved from

Nowak, K. H., Nehring, A., Tiemann, R., \& Belzen, U. z. A. (2013). Assessing students' abilities in processes of scientific inquiry in biology using a paper-and-pencil test. Journal of Biological Education, 47(3), 182-188. doi:10.1080/00219266.2013. 822747.
Putra, M. I. S., Widodo, W., \& Jatmiko, B. (2016). The development of guided inquiry science learning materials to improve science literacy skill of prospective MI teachers. Jurnal Pendidikan IPA Indonesia, 5(1), 83-93. doi:10.15294/jpii.v5i1.5794.

Schaub, G., Cadena, C., Bravender, P., \& Kierkus, C. (2016). The Language of Information Literacy:Do Students Understand?. Allendale, Michigan: Grand Valley State University.

Subekti, H., \& Martini. (2016). Representasi Pembelajaran Berbasis Penelitian pada Mata Kuliah Bioteknologi dan Salingtemas dalam Menumbuhkan Budaya Akademik di Program Studi Pendidikan IPA Unesa. Paper presented at the Seminar Nasional IPA VII Di Universitas Negeri Semarang, Semarang.

Sudira, P. (2015). Pengembangan Model "Lis-5c" pada Pendidikan Teknologi dan Kejuruan. Cakrawala Pendidikan, 34(1), 111. doi:10.21831/cp.v1i1.4145

Sugiono. (2013). Metode Penelitian Kuantitatif, Kualitatif, dan Kombinasi (Mixed Methods) (4ed. ed.). Bandung: Alfabeta.

Suwono, H., Pratiwi, H. E., Susanto, H., \& Susilo, H. (2017). Enhancement of Students' Biological Literacy and Critical Thinking of Biology Through Socio-Biological Case-Based Learning. Jurnal Pendidikan IPA Indonesia, 6(2), (213-220. doi:DOI: $\quad 10.15294 /$ jpii.v6i2. 9622.

Widodo, W. (2016). Literasi Sains Mahasiswa Calon Guru IPA Berdasarkan Permintaan Kognitf (Cognitive Demand) Pisa: 
Bagaimana Langkah Selanjutnya? Paper presented at the Seminar Nasional Pendidikan IPA VII, FMIPA UNESA

Yang, W., \& Liu, E. (2016). Development and validation of an instrument for evaluating inquirybased tasks in science textbooks. International Journal of Science Education, 38(18), 1-25. doi:10.1080/09500693.2016. 1258499 .
Yeh, Y.-F., Jen, T.-H., \& Hsu, Y.-S. (2012). Major strands in scientific inquiry through cluster analysis of research abstracts. International Journal of Science Education, 34(18), 2811-2842. doi:10.1080/09500693.2012.663 513. 